\title{
Avaliação ultrassonográfica no pós-parto de ovelhas: revisão de literatura
}

Postpartum ultrasound assessment in sheep: Literature Review

\author{
Renata Sitta Gomes Mariano ${ }^{*}$, Victor José Correia Santos ${ }^{1}$, Augusto Rionosuke Taira ${ }^{2}$, Priscila \\ Del Aguila Silva ${ }^{1}$, Mariana Garcia Kako Rodriguez ${ }^{1}$, Luciana Cristina Padilha Nakaghi ${ }^{1}$, Ricardo \\ Andres Ramirez Uscategui ${ }^{3}$, Marcus Antônio Rossi Feliciano ${ }^{1,4}$, Pedro Paulo Maia Teixeira ${ }^{5}$, Wilter \\ Ricardo Russiano Vicente ${ }^{1}$.
}
${ }^{1}$ Veterinary Preventive Medicine and Animal Reproduction Department, Faculty of Agricultural and Veterinary Sciences, Univ. Estadual Paulista "Júlio de Mesquita Filho", Jaboticabal, São Paulo, Brazil.
${ }^{2}$ Veterinary Medicine Department, Niteroi’s Anhanguera University Center, Niterói, Rio de Janeiro, Brazil.
${ }^{3}$ Institute of Agrarian Sciences, University of Jequitinhonha and Mucuri Valleys, Minas Gerais, Brazil. ${ }^{4}$ Department of Clinical of Large Animals, Federal University of Santa Maria, Santa Maria, Brazil.
${ }^{5}$ Veterinary Medicine Department, Universidade Federal do Pará (UFPA), Castanhal, Pará, Brazil.

\section{Resumo}

Puerpério é o período após a finalização do parto e acontece em escala logarítmica decrescente, especialmente durante a primeira semana após o parto, quando o útero passa por marcado remodelamento durante sua involução. No entanto, não estão totalmente elucidados os mecanismos hormonais, celulares e moleculares que regulam esse processo. Considerando a necessidade de estabelecer métodos diagnósticos precoces para a avaliação das mudanças no puerpério em ovelhas e a escassez no número de estudos sobre involução uterina, o monitoramento desse período é essencial para evitar declínio na eficiência reprodutiva, sendo que o intervalo de partos está diretamente relacionado à velocidade da involução uterina e ao retorno à atividade reprodutiva das fêmeas. Para isso, o entendimento do processo de recuperação do trato reprodutivo no pós-parto dessa espécie é de grande importância para o sucesso do sistema de produção em ovinos. Neste trabalho, revisamos o período puerperal, os mecanismos subjacentes à reprodução normal dos ovinos e a ultrassonografia para avaliar esse período na ovelha como modelo experimental ou para aplicação em Medicina Veterinária.

Palavras-chave: gestação, ultrassonografia, modo B, ovelha.

\begin{abstract}
Puerperium is the period after the completion of delivery and occurs on a decreasing logarithmic scale, especially during the first week after delivery, when uterus undergoes marked remodeling. However, hormonal, cellular, and molecular mechanisms that regulate this process are not fully understood. Considering the need to establish early diagnostic methods to evaluate changes during sheep's puerperium and the scarce number of studies on uterine involution, monitoring this period is essential to avoid declining in reproductive efficiency, as calving interval is directly related to the speed of uterine involution and the return to female reproductive activity. Therefore, understanding the postpartum reproductive tract recovery process of this species is of great importance for the success of sheep production systems. We review the puerperal period, the mechanisms underlying the normal reproduction of sheep and ultrasonography to evaluate this period as an experimental model or for application in Veterinary Medicine.
\end{abstract}

Keywords: gestation, ultrasonography, B-mode, ewe.

\section{Introduction}

Improving reproductive efficiency in domestic farm animals is critically important to the livestock industry. The postpartum period has a reproductive and economic importance because influences interval between parturitions and affects the number of offspring produced per year (Sanchez et al., 2002), mainly under intensive sheep production systems (Ababneh and Degefa, 2005). Postpartum fertility depends on two major events: uterine involution and ovarian cyclicity resumption (Jainudeen et

'Correspondência: santosvjc@gmail.com

Recebido: 12 de novembro de 2019

Aceito: 02 de julho de 2020 
al., 2004). However, there are conflicting studies regarding the uterine involution time in ewes, which may reflect differences in breeds and management.

Indeed, the influences that contribute to a low productivity in ruminants are associated with delayed uterine involution due to inflammatory and/or infectious processes, disorders in endometrial regeneration and anestrus (Sheldon and Owner, 2017). Regarding uterine pathologies, it is also important to mention metritis, uterine prolapse and hydrometra/mucometra (Scott, 2015).

Ultrasonography in small ruminants production is a non-invasive technique that may reveal details of the progressive changes in the uterus of ewes (Ioannidi et al., 2017) and has been responsible for expressive benefits to reproductive management, enabling clinical investigation, pregnancy diagnosis, and real time uterine evaluation postpartum (Hauser and Bostedt, 2002). The aim of this article is to review the particularities of the postpartum period and the use of ultrasonography to evaluate the uterus of ewes during this period.

\section{Uterine Anatomy and Postpartum Physiology}

In sheep, cattle and horses the uterus is bipartite, with prominent uterine body and a septum that separates both horns. The uterine perimetrium and myometrium share similar echogenic structure, which makes ultrasound differentiation not possible. The uterine endometrium of ewes has both aglandular caruncular and glandular intercaruncular areas (Hafez and Hafez, 2004; Wang et al., 2013). Placentation in sheep (synepitheliochorial) involves growth and union of placental cotyledons with endometrial caruncles, developing the placentomes, which are the primary sites of conceptus-maternal exchange of gases and micronutrients, such as amino acids and glucose (Bazer et al., 2012). The average gestation length is 150 days and may vary due to interference of maternal, environmental, fetal and genetic factors. If not pregnant, a new estrous cycle will occur at an average interval of 17 days (Feliciano et al., 2013).

After parturition in ruminants, the uterine involution encompass contraction and weight loss, as well as tissue renewal. The uterine involution begins immediately after parturition and involves physical shrinkage, necrosis and sloughing of caruncles, and regeneration of the endometrium. Sloughing of the uterine caruncles contributes to reduction in weight of the uterus because they take over half of the weight of the uterus (Gier and Marion, 1968; Sheldon, 2004). There is a progressive decreasing in vaginal discharge, uterine and cervical diameters that occurs due to vasoconstriction and peristaltic contractions (Leslie, 1983; Wehrend and Bostedt, 2003), reduction in uterine blood flow and endometrial vascularity, as well as a reduction of smooth muscle mass (Guilbault et al., 1984; Slama et al., 1991).

A balanced and coordinated endocrine system is important for normal reproductive function and returns to ovarian cyclicity. This requires homeostasis among gonadotrophin releasing hormones $(\mathrm{GnRH})$ from the hypothalamus, follicle stimulating hormone (FSH), luteinizing hormone ( $\mathrm{LH}$ ) and prolactin (PRL) from the adenohypophysis and prostaglandin F2-alpha (PGF2 $\alpha$ ) from the uterus and the gonadal steroids (Kota et al., 2013). After parturition, steroid hormone concentrations decrease to basal values and there is an increase in plasma FSH concentration within days after parturition that stimulates the emergence of the first postpartum follicular wave (Sheldon et al., 2008). Thus, the ability to achieve maximum reproductive efficiency depends on a thorough understanding of postpartum hormonal changes.

The postpartum fertility of sheep depends on uterine physiological involution and the return of ovarian activity (Lamraoui et al., 2017). However, there are controversial studies regarding the time for complete uterine involution and ovarian activity resumption in the postpartum period (Hayder and Ali, 2008; Nasciutti et al., 2011).

\section{Postpartum assessment of the genital tract by ultrasonography}

To maximize sheep production, it is necessary to adopt tools that enable reproductive monitoring, improving reproductive performance and herd productivity (Sharkey et al., 2001). In small ruminants, accurate evaluation of the internal organs of the reproductive tract by rectal palpation is not possible (Feliciano et al., 2013) and authors reported different intervals to complete uterine involution. Studies were conducted assessing hormonal levels (Ishwar, 1995), radiography (Tian and Noakes, 1991), ultrasonography (Fernandes et al., 2013), laparotomy (Rubianes et al., 1996) or evaluation after slaughtering (Rubianes and Ungerfeld, 1993).

In ewes, ultrasonography is routinely used for pregnancy diagnosis, but there is limited information using this technique for the evaluation of the uterine regression in this species. It has been 
reported the use of ultrasonography as a practical and efficient tool to evaluate the uterine involution during post-partum period in several species, such as cows (Sheldon and Ownes, 2017), mares (Griffin_and Ginther, 1991), goats (Ababneh and Degefa, 2005; Badawi et al., 2014; Fasulkov, 2014) and ewes (Zdunczyk et al., 2004; Hayder and Ali, 2008; Nasciutti et al., 2011, Gomes et al., 2014; Ioannidi et al., 2017).

Ultrasonography has a role in differentiating the normal or abnormal uterus during postpartum (Feldman and Nelson, 1996). It also provides additional information about uterine physiological and pathological processes, which may contribute to the development of new methods for the treatment of reproductive disorders in ruminants (Jaśkowski et al., 2013). It is also possible to diagnose uterine abnormalities after parturition, such as accumulation of lochia in the uterine lumen or the presence of retained fetal membranes, leading to a prolonged uterine involution, placental retention and other disorders, e.g. endometritis, uterine infection and hemorrhage (Hauser and Bostedt, 2002).

Obstetric intervention in cases of dystocia compromise the uterine involution during the first 24 $\mathrm{h}$ postpartum, measured by cross-sectional diameter, whereas at later time points the involution process nearly develops parallel in ewes with or without lambing disorders. In addition, obstetrics intervetion increases the risk of foetal membranes retention by up to $30 \%$ in cases of caesarean section (Ftheniakis et al., 2000; Hauser and Bostedt, 2002).

Ultrasound examination of the female reproductive system in small ruminants can be conducted using two approaches: transabdominal and transrectal (Zdunczyk et al., 2004). To evaluate the uterine involution in sheep, transabdominal approach is recommended rather than transrectal in the first week postpartum, since the uterus remains in the cranioventral portion of the abdomen (Hauser and Bostedt, 2002).

The uterine lumen and its content in a normal uterus can be easily visualized during the early stage of the puerperium, appearing enlarged and with heterogeneous echotexture due to the observation of the layers (Hauser and Bostedt, 2002), presenting up to $10 \mathrm{~cm}$ of diameter (Fernandes et al., 2013). As its size decreases progressively, it may be more difficult to image it after the $13^{\text {th }}$ day post-partum by transabdominal scanning, as reported by Ababneh and Degefa (2005).

The uterine characteristics that can be assessed by ultrasonography during postpartum are uterine diameter, distention of uterine lumen, presence, quantity and echotexture of uterine content, thickness and echotexture of uterine wall, regression of caruncles and uterine blood flow (Hauser and Bostedt, 2002; Ababneh and Degefa, 2005; Elmetwally and Bollwein, 2017).

Different intervals were reported for complete uterine involution postpartum evaluated by ultrasonography, which occurred between 17-35 days postpartum (Ali et al., 2001; Zdunczyk et al., 2004; Ababneh and Degefa, 2005; Badawi et al., 2014; Fasulkov, 2014; Medan and El-Daek, 2015; Elmetwally and Bollwein, 2017). Gomes et al. (2014) reported a slower reduction of uterine depth in ewes with twin parturition compared to singleton parturition, but uterine depth decreased in all ewes during postpartum period with more that $50 \%$ of total uterine regression observed from day 1 to day 16 after parturition. Accordingly, Hauser and Bostedt (2002) reported uterine size decreasing by $50 \%$ after five days postpartum. However, Rubianes and Ungerfeld (1993) reported that $97 \%$ of the uterine involution in the animals evaluated occurred approximately on day 17 postpartum. Other researchers found that this involution occurs around 28 days postpartum (Regassa and Noakes, 1999) or between the fourth and fifth week postpartum (Hayder and Ali, 2008).

The ability to measure changes in blood flow during postpartum period provides a promising diagnostic tool for assessing the status of uterine involution during this period. Doppler has been used for several years to identify postpartum uterine involution in women, reporting an association between uterine blood flow and delayed uterine involution (Mulic-Lutvica and Axelsson, 2007; Guedes-Martins et al., 2015). In ruminants, uterine blood flow during the postpartum period was assessed in cows (Krueger, 2009; Heppelmann et al., 2013), ewes and goats (Elmetwally and Bollwein, 2017; Ioannidi et al., 2017). Preliminary finds in ewes have indicated that blood flow and diameter of the uterine artery decrease progressively after parturition, starting soon after lambing. Changes are of greater magnitude during the first post-partum week and it decrease significant after the $20^{\text {th }}$ day post-partum compared to findings immediately after lambing (Ioannidi et al. 2017). Elmetwally and Bollwein (2017) also reported significantly decrease in uterine blood flow during the initial postpartum period in goats and sheep, especially during the first nine days postpartum, and these important changes can be explained because of loss of metabolic requirements of the fetus and placenta.

\section{Conclusion}

This literature review shows that ultrasonography can be a great and accurate method for assess 
and elucidate the process of uterine involution in ewes, mainly because uterine structures cannot be assessed by rectal or abdominal palpation in this species. Studies reviewed in this article presented that the ultrasonography can be a non-invasive tool to evaluate details of the progressive changes in the uterus during the postpartum. Thus, the monitoring of this period and the capability to early diagnosis of intercurrences could improve the survival rate of obstetric patients and reproductive life, together with achievement of a satisfactory interval between.

\section{Acknowledgments}

Grant \#2015/18519-8, São Paulo Research Foundation (FAPESP).

\section{References}

Ababneh MM, Degefa, T. Ultrasonic assessment of puerperal uterine involution in Balady goats. J Vet Med A Physiol Pathol Clin Med, n.52, p.244-248, 2005.

Ali A, Salem AA, El-Din Zain A. Ultrasonographic assessment of postpartum uterine involution and onset of ovarian activity in the Ossimi ewe. Proc Egypt Soc Anim Reprod Theriogenology, 2001.

Badawi ME, Makawi, SEA, Abdelghafar RM, Ibrahim MT. Assessment of postpartum uterine involution and progesterone profile in nubian goats (Capra Hircus). J Adv Vet Anim Res, v.1, n.2, p.3641, 2014.

Bazer FW, Song G, Kim J, Dunlap KA, Satterfield MC, Johnson GA, Burghardt RC, Guoyao W. Uterine biology in pigs and sheep. J Anim Sci Biotec, v.3, n.1, p.23, 2012.

EImetwally M, Bollwein $\mathbf{H}$. Uterine blood flow in sheep and goats during the peri-parturient period assessed by transrectal Doppler sonography. Anim Repro Sci, n.176, p.32-39, 2017.

Fasulkov, I. Ultrasonography of uterine involution in goats. J Fac Vet Med, Istanbul University, n.40, p.63-69, 2014.

Feldman EC, Nelson RW. Canine and Feline Endocrinology and Reproduction. WB Saunders Company 2nd ed. Toronto:, p.785, 1996.

Feliciano MAR, Oliveira MEF, Vicente WRR. Ultrassonografia na Reprodução Animal. In: Biotécnicas Reprodutivas em Ovinos e Caprinos. MedVet, 1ª ed, São Paulo, p.121-146, 2013

Fernandes CES, Cigerza CF, Pinto GS, Miazi C, Barbosa-Ferreira M, Martins CF. Características do parto e involução uterina em ovelhas nativas do pantanal brasileiro. Ciên Anim Bras, v.14, n.2, p.245252, 2013.

Ftheniakis GC, Leontides L, Amiridis GS, Saratsis P. Incidence risk and clinical features of retention of fetal membranes in ewes in 28 flocks in southern Greece. Prev Vet Med, v. 43, p.85-90, 2000.

Gier, HT, Marion, GB. Uterus of the cow after parturition: involutional changes. Am J Vet Res, v.29, p. 83-96, 1968.

Gomes MGT, Macedo-Júnior GL, Ferreira MIC, Borges I, Varago FC, Lago LA, Henry M. Some aspects of the puerperium after singleton and twin parturitions in Santa Inês ewes submitted to energy restriction during pregnancy. Small Rumin Res, v.120, n.2, p.219-223, 2014.

Griffin PG, Ginther OJ. Uterine morphology and function in postpartum mares. J Equine Vet Sci, v. 11, n.6, p.330-339, 1991.

Guedes-Martins L, Gaio AR, Saraiva J, Cunha A, Macedo F, Almeida H. Uterine artery impedance during the first eight postpartum weeks. Sci Rep, n.5, p.8786, 2015.

Guilbault LA, Thatcher WW, Foster DB, Caton D. Relationship of 15-keto-13, 14-dihydroprostaglandin $F_{2 \alpha}$ concentrations in peripheral plasma with local uterine production of $\mathrm{F}$ series prostaglandins and changes in uterine blood flow during the early postpartum period of cattle. Biol Rep, n.31, p.870-878, 1984.

Hafez ESE, Hafez B. Reprodução Animal. 7.ed. Barueri: Manole, 2004.

Hauser B, Bostedt H. Ultrasonographic observations of uterine regression in the ewe under different obstetrical conditions. J Vet Med, n.49, p.511-516, 2002.

Hayder M, Ali A. Factors affecting the postpartum uterine involution and luteal function of sheep in the subtropics. Small Rumin Res, n.79, p.79-174, 2008.

Heppelmann M, Krueger L, Leidl S, Bollwein H. Transrectal Doppler sonography of uterine blood flow during the first two weeks after parturition in cows. J Vet Sci, n.14, p.323-327, 2013.

Ioannidi KS, Mavrogianni VS, Valasi I, Barbagianni MS, Vasileiou NGC, Amiridis GS, Fthenakis GC, Orfanou DC. Ultrasonographic examination of the uterus of ewes during the post-partum 
period. Small Rumin Res, n.152, p.74-85, 2017.

Ishwar AK. Pregnancy diagnosis in sheep and goats: a review. Small Rumin Res, n.17, p.37-44, 1995.

Jainudeen MR, Wahid H, Hafez ESE. Ovinos e caprinos. Hafez B, Hafez ESE, Reprodução animal (7th ed.), Manole, São Paulo, p.173-182, 2004.

Jaśkowski JM, Włodarek J, Gehrke M, Boryczko Z. Use of Doppler ultrasonography in the reproduction of cows. Medy Wetery, n.69, p.585-591, 2013.

Kota SK, Gayatri K, Jammula S, Kota Siva K, Krishna SVS, Meher Lilit K, Kiritikumar D. Endocrinology of parturition. Indian J Endocrinol Metab, n.17, p.50-59, 2013.

Krueger L, Koerte J, Tsousis G, Herzog K, Flachowsky G, Bollwein H. Transrectal Doppler sonography of uterine blood flow during the first 12 weeks after parturition in healthy dairy cows. Anim Rep Sci, n.114, p.23-31, 2009.

Lamraoui R, Farida A, Bouzebda Z. Resumption of ovarian cyclicity during postpartum in winterlambing ouled Djellal ewes in Algerian semi-arid area. Global Vet, n.18, p.27-30, 2017.

Leslie KE. The events of normal and abnormal postpartum reproductive endocrinology and uterine involution in dairy cows: a review. Can Vet J, v.24, n.3, p.67-71, 1983.

Medan MS, Al Daek T. Uterine involution and progesterone level during the postpartum period in Barbary ewes in north Libya. Open Vet J, v.5, n.1, p.18-23, 2015.

Mulic-lutvica A, Axelsson O. Postpartum ultrasound in women with postpartum endometritis, after cesarean section and after manual evacuation of the placenta. Acta Obstet Gynecol Scand, v.86, n.2, p.210-217, 2007.

Nasciutti NR, Oliveira RSBR, Silva NC, Franco MTF, Tsuruta AS, Ferreira IC, Sauti JPE. Avaliação clínica da involução uterina em ovelhas da raça Santa Inês. Biosci J, n.27, p.649-655, 2011.

Regassa F, Noakes DE. Acute phase protein response of ewes and the release of PGFM in relation to uterine involution and the presence of intrauterine bacteria. Vet Rec, n.144, p.502-506, 1999.

Rubianes E, Ungerfeld R. Uterine involution and ovarian changes during early postpartum in autumn lambing Corriedale ewes. Theriogenology, n.40, p.365-372, 1993.

Rubianes E, Ungerfeld R, Vifroles C, Carbajal B, De Castro T, Ibarra D. Uterine involution time and ovarian activity in weaned and suckling. J Anim Sci, n.76, p.153-155, 1996.

Sanchez MA, Garcia P, Menendez S, Sanchez B, Gonzalez M, Flores JM. Fibroblastic growth factor receptor (FGF-R) expression during uterine involution in goat. Anim Rep Sci, n.69, p.25-35, 2002.

Scott P. Sheep Medicine. Boca Raton: CRC Press, 2015.

Sharkey S, Callan RJ, Mortimer R, Kimberling C. Reproductive techniques in sheep. Vet Clin North Am Food Anim Prac, n.17, p.435-455, 2001.

Sheldon IM. The pospartum uterus. Vet Clin Food Anim J, n.20, p.569-591, 2004.

Sheldon IM, Williams EJ, Miller ANA, Nash DM, Herath S. Uterine diseases in cattle after parturition. Vet J, v.176, n.1, p.115-121, 2008.

Sheldon IM, Owens SE. Postpartum uterine infection and endometritis in dairy cattle. Anim Rep, n.14, p.622-629, 2017.

Slama H, Vaillancourt D, Goff AK. Pathophysiology of the puerperal period: Relationship between prostaglandin E2 (PGE2) and uterine involution in the cow. Theriogenology. n.36, p.1071-1090, 1991.

Tian W, Noakes DE. A radiographic method for measuring the effect of exogenous hormone therapy on uterine involution in ewes. Vet Rec, n.129, p.436-466, 1991.

Wang Y, Wang C, Hou Z, Miao K, Zhao H, Wang R, Guo M, Wu Z, Tian J, An L. Comparative analysis of proteomic profiles between endometrial caruncular and intercaruncular areas in ewes during the peri-implantation period. J Anim Sci Biotech, n.4, p.39, 2013.

Wehrend A, Bostedt H. Examinations on the incidence of cervical dystocia and disorders of cervical involution in the cow postpartum. Deut Tierärztl Woch, v.110, p.483-486, 2003.

Zdunczyk S, Milewski S, Barański W, Janowski T, Szczepański W, Jurczak A, Raś A, Lesnik M. Postpartum uterine involution in primiparous and pluriparous polish longwool sheep monitored by ultrasonography. Bull Vet Inst Pulawy, n.48, p.255-257, 2004. 